\title{
Effects of conspecific and heterospecific larval tracks on the oviposition behaviour of the predatory ladybird, Harmonia axyridis (Coleoptera: Coccinellidae)
}

\author{
Hironori YASUDA, TaKumi TAKAGI and KaZUNOBU KOGI
}

Department of Agriculture, Yamagata University, Tsuruoka, Yamagata 997-8555, Japan; e-mail: hyasuda@tds1.tr.yamagata-u.ac.jp

Key words. Harmonia axyridis, ladybird, oviposition, oviposition-deterring pheromone, larval track

\begin{abstract}
The effect of the oviposition deterring pheromone (ODP) in the larval tracks of conspecific and heterospecific ladybirds on oviposition in Harmonia axyridis Pallas was studied in semi natural conditions. Gravid females of $H$. axyridis were deterred from ovipositing on plants contaminated with conspecific larval tracks, but not on those with heterospecific tracks. H. axyridis females spent significantly less time on plants contaminated with conspecific ODP than on those with heterospecific ODP. This behaviour may account for why fewer eggs were laid on plants contaminated with conspecific ODP.
\end{abstract}

\section{INTRODUCTION}

Recently, there has been an increase in our understanding of how females of predatory insects assess the quality of patches of prey as potential oviposition sites (Hemptinne et al., 1992, 1993; Rủžička, 1994, 1996, 1997a; Dixon, 1997; Doumbia et al., 1998). The survival of their larvae mainly depends on the quality and quantity of prey in a patch (Kindlmann \& Dixon, 1993; Hemptinne et al., 1993). The number of eggs laid by females in the field is influenced by prey abundance (Wratten, 1973; Mills, 1982). In addition the presence of an oviposition deterring pheromone (ODP) has been shown to be important in the assessment of patch quality in several insect species (Rủžička, 1994, 1996, 1997a, b; Dixon, 1997; Doumbia et al., 1998; Růžička \& Havelka, 1998).

Most of the studies on oviposition in predatory ladybirds were done in small vials or Petri dishes (Evans \& Dixon, 1986; Hemptinne et al., 1992, 1993; Doumbia et al., 1998). There is now a need to confirm the results so obtained using more natural experimental conditions. For instance, in the presence to conspecific larvae of Adalia bipunctata (L.) females might leave a patch without ovipositing (e.g., Hemptinne et al., 1992). The presence of ODPs in other ladybird species also needs to be established.

Coccinella septempunctata L. and Harmonia axyridis Pallas are common species in Japan, and in spring often coexist in aphid colonies on trees (Hironori \& Katsuhiro, 1997). H. axyridis larvae often eat $C$. septempunctata larvae and appear to be better adapted to survive interspecific predation (Yasuda et al., unpubl.). Of these two species, C. septempunctata arrives and oviposits in patches of aphids first (Hironori \& Katsuhiro, 1997). The role of ODP in the assessment of oviposition sites by these species is unknown.

The aim of this study was to determine the effect of ODPs in the tracks of conspecific and heterospecific larvae on the selection of oviposition sites by $H$. axyridis. In addition, the experiments were designed to simulate more closely field condition.

\section{MATERIALS AND METHODS}

Eggs of $H$. axyridis were obtained from Aguro-Kanesho Corporation and stock cultures were raised in the laboratory at $25 \pm 1^{\circ} \mathrm{C}$ and a $15 \mathrm{~L}$ : 9D photoperiod and fed the aphid, Aphis craccivora Koch. Mated females were kept individually in plastic containers on excess aphids $(9 \mathrm{~cm}$ in diameter and $8 \mathrm{~cm}$ in height) and the females that laid eggs in the previous 24 hours were used in the experiment.

Broadbean plants, Vicia faba L., $20 \mathrm{~cm}$ in height, planted in standard plant pots, were used in the experiment. Prior to use, each of three leaves on each plant had larvae confined on them for 12 hours: either (1) two third instar larvae of $H$. axyridis; or (2) two third instar larvae of $C$. septempunctata. This was achieved by covering each leaf with a small nylon bag after placing the two larvae on the leaf. A plant with larval tracks was referred to as a plant with ODP. Then, each broadbean plant was infested with approximately 200 adult aphids of $A$. craccivora. A clear plastic cage $(15 \times 50 \mathrm{~cm}$ and $30 \mathrm{~cm}$ in height $)$ was placed over two plants, which were kept $20 \mathrm{~cm}$ apart, one with ODP +200 aphids and the other without ODP +200 aphids. A gravid female of $H$. axyridis was released into the cage.

The experiment was started at 0600 after which observations were made at $0900,1200,1500,1800$, and 0600 . The relative position of the female and any eggs and the number of eggs laid were recorded at each observation. Eggs were counted and then removed by means of a brush. This was repeated ten times using a different female each time.

All experiments were carried out at a constant temperature $\left(25 \pm 1^{\circ} \mathrm{C}\right)$ and photoperiod $(15 \mathrm{~L}: 9 \mathrm{D})$ in the laboratory.

\section{RESULTS AND DISCUSSION}

Gravid females of $H$. axyridis were deterred from ovipositing on plants contaminated with conspecific larval tracks (Fisher's LSD: $\mathrm{P}<0.05)$, but not with heterospecific tracks $(\mathrm{F}=0.93, \mathrm{P}>$ 0.05; Fig. 1A). Doumbia et al. (1998) speculated that a similar response shown by the ladybird, $A$. bipunctata, might serve to reduce egg cannibalism, and the weak response to heterospecific ODP was attributed to a lower frequency of encounters with heterospecifics as each species of ladybirds occupies a different but overlapping habitat. The hypothesis suggested by Doumbia et al. (1998) might apply to the response of $H$. axyridis to conspecific ODP observed in this study because egg cannibalism has been recorded for the species in the field (Hironori \& Katsuhiro, 1997; Sato, 1997). However, the weak response to heterospecific ODP is difficult to explain because $H$. axyridis usually coexists with $C$. septempunctata in many habitats in Japan (Takahashi, 1987; Hironori \& Katsuhiro, 1997). Field studies suggest that $C$. septempunctata avoids eating $H$. axyridis eggs 
(Hironori \& Katsuhiro, 1997; Sato, 1997) and when the larvae of these two species coexist, $H$. axyridis survives significantly better than C. septempunctata (Hironori \& Katsuhiro, 1997). Agarwala \& Dixon (1992) showed that the eating of A. bipunctata eggs had a negative effect on the larval development of $C$. septempunctata. It is, therefore, reasonable to assume that the weak response of $H$. axyridis females to the ODP of $C$. septempunctata reflected the low risk of predation from this species.

H. axyridis females laid more eggs on plants infested with aphids than on the walls of the cages, but the difference was not significant $(\mathrm{t}=1.65, \mathrm{df}=35, \mathrm{P}>0.05$; Fig. $1 \mathrm{~B})$. Predatory ladybirds do not always oviposit where prey is abundant. Many species of ladybird prefer to lay eggs in aphid colonies (e.g., Wratten, 1973; Mills, 1982), but females of C. septempunctata are known to lay eggs in places without aphids (Sakuratani \& Nakamura, 1997). The present study suggested that females of H. axyridis preferred to lay eggs close to aphids.

Time spent by ladybirds on plants contaminated by ODP is shown in Fig. 2. H. axyridis females spent significantly less time on plants contaminated with conspecific ODP than with heterospecific ODP $\left(\chi^{2}=4.16, \mathrm{P}<0.05\right)$ and spent less than $50 \%$ of the time on the walls of the cages. This behaviour would result in them laying fewer eggs on plants contaminated with conspecific ODP. This is consistent with our findings and those of the earlier experiments of Doumbia et al. (1998) using $A$. bipunctata.

(A)

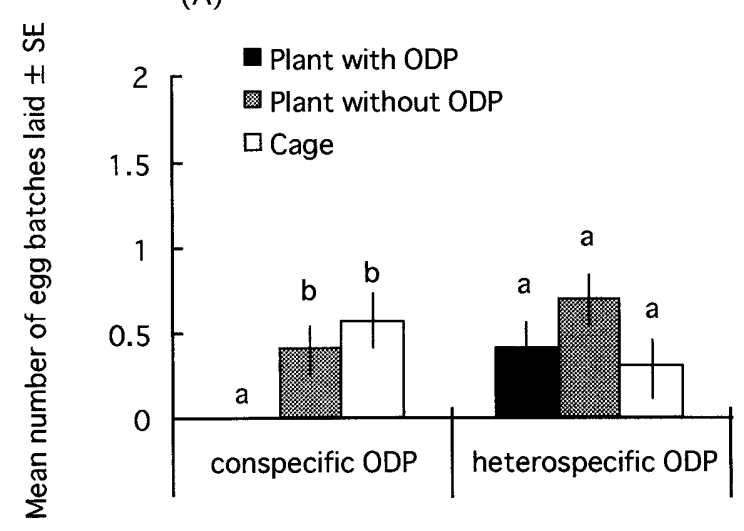

(B)

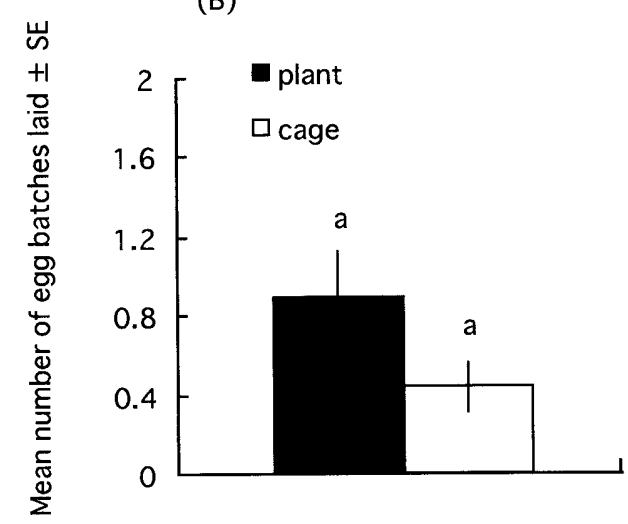

Fig. 1. Mean number of egg batches laid by females: (A) Response to ODP; means with different letters are significantly different (Fisher's LSD: $\mathrm{P}<0.05$ ), and (B) Oviposition site; means with same letter are not significantly different (t-test: $\mathrm{P}>0.05$ ).

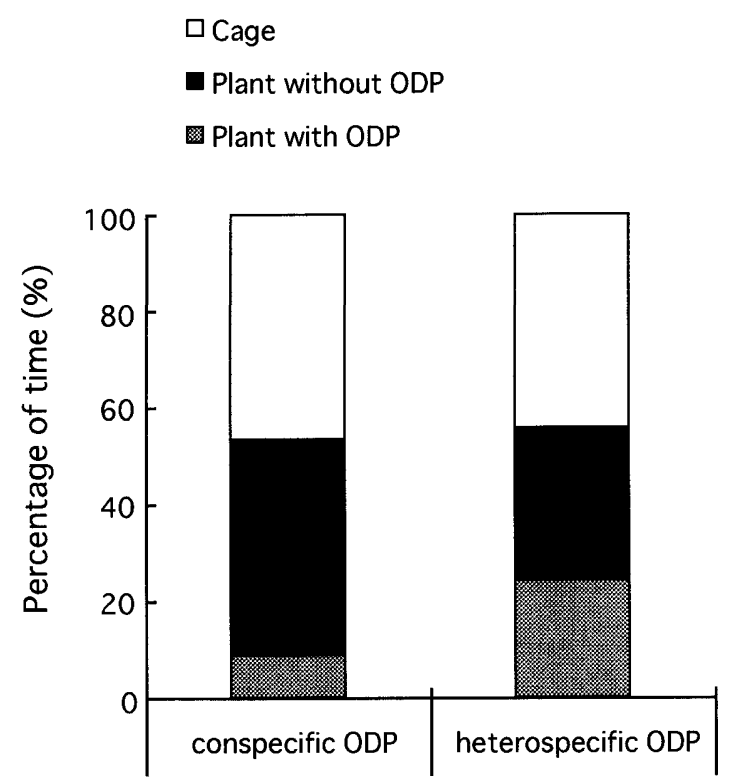

Fig. 2. Percentage of time female of $H$. axyridis spent in each place based on five observations replicated ten times.

ACKNOWLEDGEMENTS. We thank A.F.G. Dixon, B.K. Agarwala, and an anoymous reviewer for their helpful comments and language correction, and S. Kinoshita for sending us $H$. $a x y$ ridis eggs.

\section{REFERENCES}

Agarwala B.K. \& Dixon A.F.G. 1992: Laboratory study of cannibalism and interspecific predation in ladybirds. Ecol. Entomol. 17: 303-309.

Dixon A.F.G. 1997: Patch quality and fitness in predatory ladybirds. In Dettner P. (ed) : Vertical Food Web Interactions. Springer-Verlag, Heidelberg, pp. 205-222.

Doumbia M., Hemptinne J.-L. \& Dixon A.F.D. 1998: Assessment of patch quality by ladybirds: role of larval tracks. Oecologia 113: 197-202.

Evans E.W. \& Dixon A.F.G. 1986: Cues for oviposition by ladybird beetles (Coccinellidae): response to aphids. J. Anim. Ecol. 55: 1027-1034.

Hemptinne J.-L., Dixon A.F.G. \& Coffin J. 1992: Attack strategy of ladybird beetles (Coccinellidae): Factors shaping their numerical response. Oecologia 90: 238-245.

Hemptinne J.-L., Dixon A.F.G., Doucet T.-L. \& Petersen J.-E. 1993: Optimal foraging by hoverflies (Diptera: Syrphidae) and ladybirds (Coleoptera: Coccinellidae): Mechanism. Eur. J. Entomol. 90: 451-455.

HiRonori Y. \& Katsuhiro S. 1997: Cannibalism and interspecific predation in two predatory ladybirds in relation to prey abundance in the field. Entomophaga 42: 153-163.

Kindlmann P. \& Dixon A.F.G. 1993: Optimal foraging in ladybird beetles (Coleoptera: Coccinellidae) and its consequences for their use in biological control. Eur. J. Entomol. 90: 443-450.

Mills N.J. 1982: Voracity, cannibalism and coccinellid predation. Ann. Appl. Biol. 101: 144-148.

RƯŽIČKA Z. 1994: Oviposition-deterring pheromone in Chrysopa oculata (Neuroptera: Chrysopidae). Eur. J. Entomol. 91: 361-370. 
RŮŽIČKA Z. 1996: Oviposition-deterring pheromone in chrysopids: Intra- and interspecific effects. Eur. J. Entomol. 93: $161-166$.

RƯžIČKA Z. 1997a: Persistence of the oviposition-deterring pheromone in Chrysopa oculata (Neur.: Chrysopidae). Entomophaga 42: 107-112.

RƯžIČKA Z. 1997b: Recognition of oviposition-deterring allomones by aphidophagous predators (Neuroptera: Chrysopidae, Coleoptera: Coccinellidae). Eur. J. Entomol. 94: 431-434.

RƯŽıČKA Z. \& HAVELKA J. 1998: Effects of oviposition-deterring pheromone and allomones on Aphidoletes aphidimyza (Diptera: Cecidomyiidae). Eur. J. Entomol. 95: 211-216.
SakuRatani Y. \& NakamuRa Y. 1997: Oviposition strategies of Coccinella septempunctata (Col.: Coccinellidae). Entomophaga 42: 33-40.

SAто S. 1997: Effects of Cannibalism and Intraguild Predation on the Ladybird Assemblage. Ms Thesis, Yamagata University, Yamagata, $80 \mathrm{pp}$.

TAKAHASHI K. 1987: Differences in oviposition initiation and sites of lady beetles, Coccinella septempunctata and Harmonia axyridis (Coleoptera: Coccinellidae) in the field. Jpn. J. Appl. Entomol. Zool. 31: 253-254.

WRATTEN S.D. 1973: The effectiveness of the coccinellid beetle, Adalia bipunctata (L.) as a predator of the lime aphid, Eucallipterus tiliae L. J. Anim. Ecol. 42: 785-802.

Received January 6, 2000; accepted August 15, 2000 